\title{
Knowledge and qualification of three ancient masonry churches in Pomarico, Italy
}

\author{
A. Guida, M. Laterza, M. D'Amato \& A. Pagliuca \\ Department of European and Mediterranean Cultures: Architecture, \\ Environment, Cultural Heritage (DiCEM), University of Basilicata, Italy
}

\begin{abstract}
Materials characterization represents a crucial point for the assessment of structural safety of old masonry structures. It usually comprises visual inspections, drilling and mechanical tests on site and of some laboratory tests on masonry samples. However, their results can significantly vary since the masonry may be typically very irregular and heterogeneous in a structure.

Recently, many efforts have been conducted in developing standard procedures of performing and interpreting the data of experimental tests. In this way on-site results may be repeated and compared among them for structural diagnosing and monitoring, and for controlling interventions locally applied within a structure. Moreover, it is also possible to classify potential pathological events and, consequently, to implement innovative solutions that could extend the interventions durability.

In this paper the analyses and qualifications of the three ancient masonry churches in Pomarico (Italy) are presented. The obtained on-site results of nondestructive tests and the restorations interventions are illustrated and compared among them.
\end{abstract}

Keywords: construction systems, masonry qualification, diagnosis, analysis.

\section{Introduction}

The conservation and restoration of historic buildings may be successfully performed only with an in-depth knowledge of materials, structural details and construction techniques [1]. This is due to the fact that very often these buildings are very complex because of their typological heterogeneity, structural and technological characteristics [2]. 
Therefore, the diagnostic phase represents an essential and crucial point for assessing the structural response and for designing the more appropriate interventions, especially if inadequate economical resources are available by the structures owners. The monuments conservation has been always a topic of particular attention for designers; in fact, in the Athens Charter (1931) is stated that "the preservation of artistic and archaeological heritage involves all states that are guardians of civilization [...] and it hopes that they can express their interest for the heritage preservation that are expression of civilization".

This paper focuses on the process of material knowledge of existing masonry structures, with particular regard to in-situ double flat-jacks test. At this aim three case studies of old masonry churches in Pomarico (Italy) are chosen: the Madonna del Carmine church, the Pio Monte dei Morti church, and the San Rocco church.

\section{Methodological approach}

In general the methodological approach for the knowledge and qualification of an existing structure starts with a preliminary data acquisition phase. It consists of a direct survey of the building characteristics and conditions, a research of project documentation, and an identification of all events that affected the structure during its construction and throughout the building life. Then, very precise decisions may be made for designing the interventions and, hence, for restoring the building. In this way, a more flexible approach may be followed, instead of a rigid and generic design-model, incapable of interpreting the unique features of the building in exam.

The diagnostic phase helps the designer to single out any structural pathology and to estimate the material properties. At this scope to date are used different procedures rather heterogeneous and not comprehensively systemized and documented that can be grouped as follows [3]:

- NON-DESTRUCTIVE TESTS: that is to say the tests undertaken directly on the in-situ specimen without causing any damage (these tests do not really require any material survey) and without compromising its functionality. They can be undertaken directly on a structure. The limit of this investigation methodology is related to the results that could be obtained which, in general, provide only qualitative but not quantitative and/or numerical indications.

- DESTRUCTIVE TESTS: these are all investigations undertaken directly on the object by taking out samples of material that will usually be analysed in a laboratory. They provide quantitative results of the material conditions and characteristics, although localised, i.e. related only to the parts from which the samples have been taken. The limit of this methodology is related to the specificity of provided information, which is not always explicit with regard to the condition of the whole building and is depending on the procedure test.

However, it should be remembered that many of these techniques could be combined to enable the collection of data, which is qualitatively and quantitatively correct and pertinent to the whole building. This approach is useful both for the classification of building pathologies of interest to the building and for the 
application of innovative solutions that will ensure durability of the restoration interventions [4].

This paper discusses only on the double flat-jack test that falls, in according to the previous classification, into the destructive tests group. This test, originally developed for the field of rock mechanism, was successfully adapted for using of masonry structures. It is performed by the means of two flat-jacks inserted into two slots derived with two cuts within the masonry element. By increasing the oil pressure into the flat-jacks a local in-situ compressive test on the masonry is reproduced. The test may be conducted up to the masonry local-failure and, by measuring the local vertical displacement, a stress-strain relationship may be derived. Particular attention has to be paid to the fact that the flat-jack pressure is not exactly equal to the compressive stress acting on the masonry investigated. The latter may be derived with the following expression:

$$
\mathrm{f}_{\mathrm{m}}=\mathrm{K}_{\mathrm{m}} \times \mathrm{K}_{\mathrm{a}} \times \mathrm{p}
$$

where $K_{a}(\leq 1)$ is the ratio of jack bearing area in contact with masonry to the slot bearing area, $K_{m}(\leq 1)$ is the parameter depending on the applied jack, and $p$ the actual oil pressures. It is easy to note that therefore $f_{m}$ is always less than $p$.

Indications and recommendations on the double flat jack test may be found in the ASTM standards $[5,6]$, or in the RILEM $[7,8]$.

\section{Case studies}

In this paper are discussed the double flat-jack results obtained during in-situ experimental campaigns carried out on three different case studies. In particular three different ancient masonry churches built in Pomarico (a little town in the southern part of Italy) are considered. For each case study is reported a brief description of structure characteristics and details of the double flat-jack tests carried out. Then, the experimental results are discussed and compared among them.

\subsection{The church of Madonna del Carmine}

This church, dedicated to the Madonna del Carmine, was originally constructed in $1575 \mathrm{AC}$ and, after a total collapse, was completely rebuilt in masonry. It is placed in the periphery of Pomarico and, after a long period of abandon, it has been recently restored by strengthening the load-bearing elements (arches, vaults and pillars) and by repairing plasters and decorations. The church, consisting in plan of a central nave of two bays and of lateral aisles, is $20.00 \mathrm{~m}$ wide and $18.00 \mathrm{~m}$ long, reaching the maximum height of $11.00 \mathrm{~m}$. As for the masonry details, it results that the load-bearing walls and free/engaged pillars are in stone of irregular size with mortar that frequently, and especially in the outer surface, is in powdered form.

An experimental campaign was planned on this church and carried out in order to estimate the quality and the mechanical properties of the masonry, and for designing the necessary structural interventions. In total, it consisted of visual 
inspections, sonic tests, single and double flat-jack tests, and penetrometic tests. The total test planning performed is reported in Figure 1 with the identification of each test. Whereas, in Figure 2 is reported a detail of the masonry unit investigated with the double flat-jack test here discussed and the arrangement of the measurement equipment.

\begin{tabular}{|l|c|}
\hline \multicolumn{2}{|c|}{ TESTS LEGEND } \\
\hline \multicolumn{1}{|c|}{ TEST PERFORMED } & $\mathfrak{n}^{\circ}$ tot. \\
\hline DFJ - DOUBLE FLAT-JACK TEST & 1 \\
\hline S- SONIC TEST & 3 \\
\hline E- ENDOSCOPIC TEST & 6 \\
\hline P- PENETROMETRIC & 3 \\
\hline
\end{tabular}

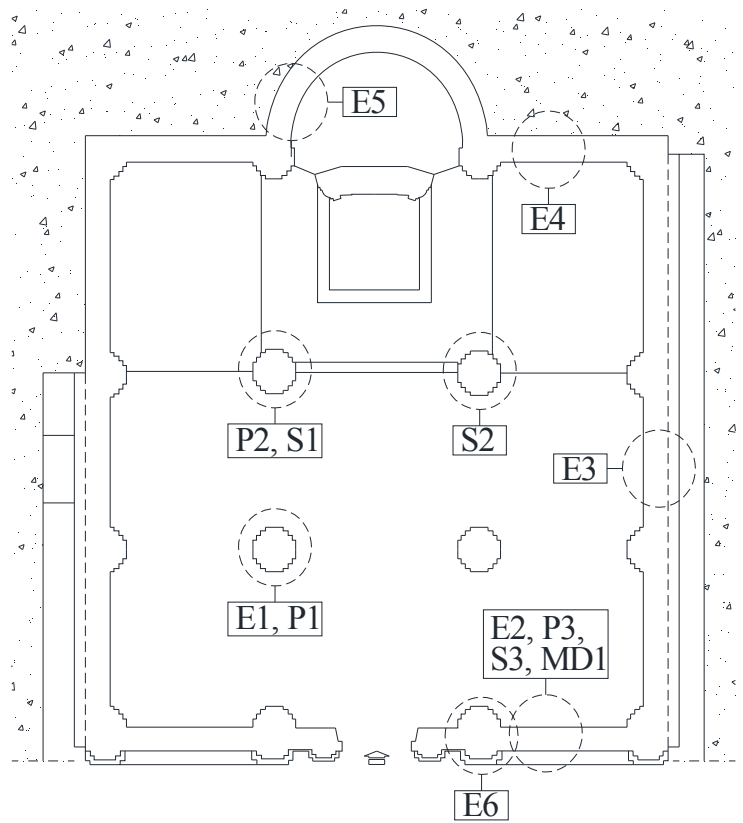

Figure 1: Test planning of the Madonna del Carmine church in Pomarico.
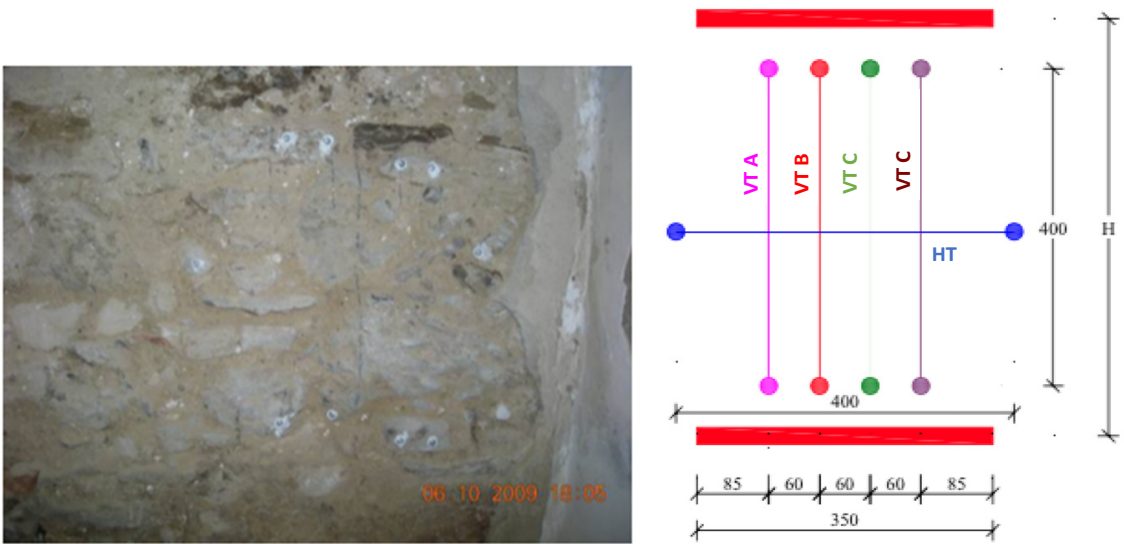

Figure 2: Details of the masonry texture investigated with the double flat-jack test and arrangement of measurement equipment. 


\subsection{The church of Pio Monte dei Morti}

The church of Pio Monte dei Morti (Figure 3) is located in the city centre of Pomarico [9], close to the old church (now destroyed) of San Michele Arcangelo and near the ruins of the ancient castle as well; it is in an urban fabric strongly articulated and characterized by narrow streets, according to the usual typology of the historical centres of the area. The building has a very importance role in the history [10] of the city, although it was closed for many decades; it was abandoned and made the subject of repeated vandalism (in fact, it was removed the interior decorative ornament, the floor and the main altar, as well), assuming the appearance of a ruin. Inside, there was props and protection structures realized after the earthquake of November 1980.

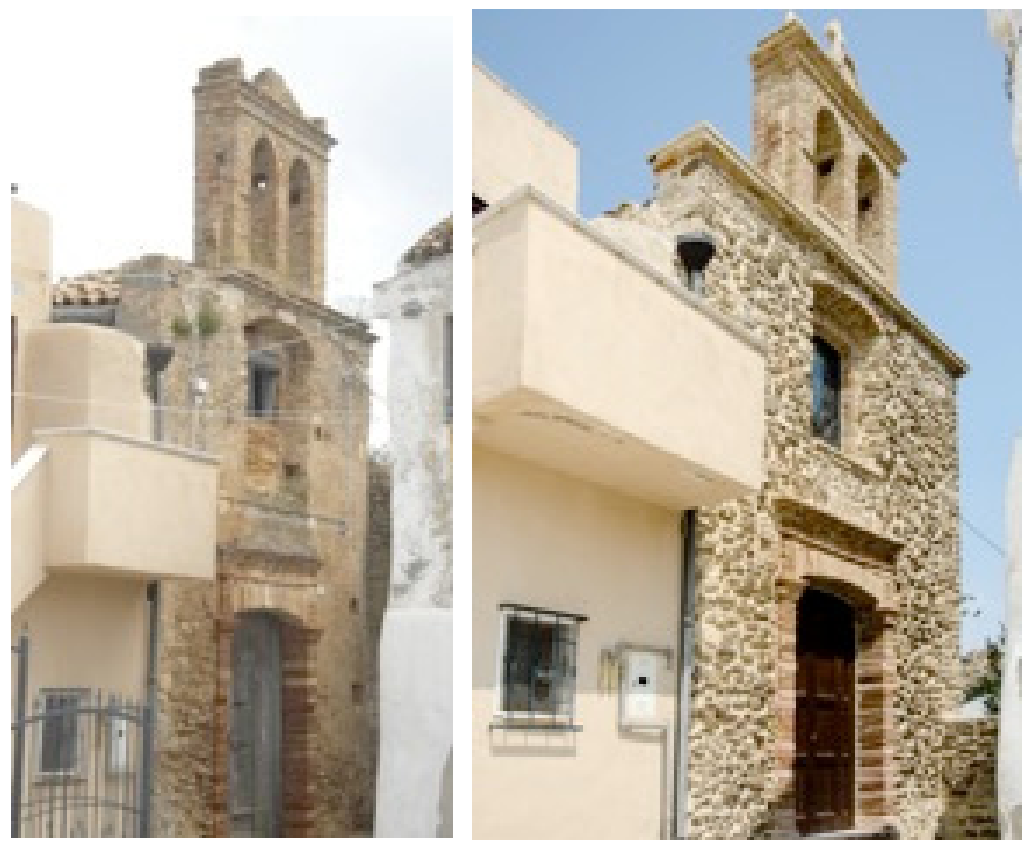

Figure 3: The church of Pio Monte dei Morti before (left) and after (right) recovery intervention.

The church has a single nave ending with the presbytery; in the nave, on the lateral walls, are located two altars. It has a length of approximately $11.00 \mathrm{~m}$ and a height of about $6.50 \mathrm{~m}$ in the nave (whose cover is constituted by a barrel vault with groin) and about $8.50 \mathrm{~m}$ in the presbytery (whose cover is constituted by a cross vault). The church was built using masonry load-bearing in local stone very irregular (according to the traditional local construction systems) [11]. The main facade is onto a small, narrow urban street. The entrance is constituted by a mail door, which does not have decorations, but that is defined by simple sequence of clay bricks to form the architrave and door jamb; above the main door, there is a 
large window that is the natural light point for the nave; the facade ends with a double sequences of arches, that form the bell gable of the church.

Regarding the lateral sides, the right one is close to a private garden, while the opposite one (left side) was on a private building that was built added to the church. The behind side shows a significant crack (in the vertical guideline); it is in an area heavily tampered, with two closed windows and a central ones, largest than the other but equally closed using brick. So, the masonry has modified several times the geometry of the loads (and of the formal type as well); it has reduced its resistance and load bearing capacity. The roof, as said before, consists of a barrel vault (nave) and a cross vault (presbytery) whose buttress was realized using topsoil (according to the local construction system) to form an inclined plane on which were placed the brick tiles to form the roof.

\subsection{The church of San Rocco}

The building, dating from the seventeenth century, is of great importance for the pastoral and social activities for the community, becoming a key element in the history of the city. The church of San Rocco al Tempone, located on the installation of a previous building first consecrated to St. James and then to Saint Sebastian and finally to St. Rocco in 1544. It, a single nave with an apse, presents along the left side in the back of the liturgical hall, next to the apse area, a devotional chapel (the Chapel of San Rocco). The church is made of bearing walls and vaulted systems for closing horizontal coverage, and externally looks, however, pitched covered with tiles.

The church (Figure 4) has a very important pathological condition that affects all the part and elements of the building. In fact, because of the total disconnection of the brick tiles on the roof and of the absence of a system for the draining of

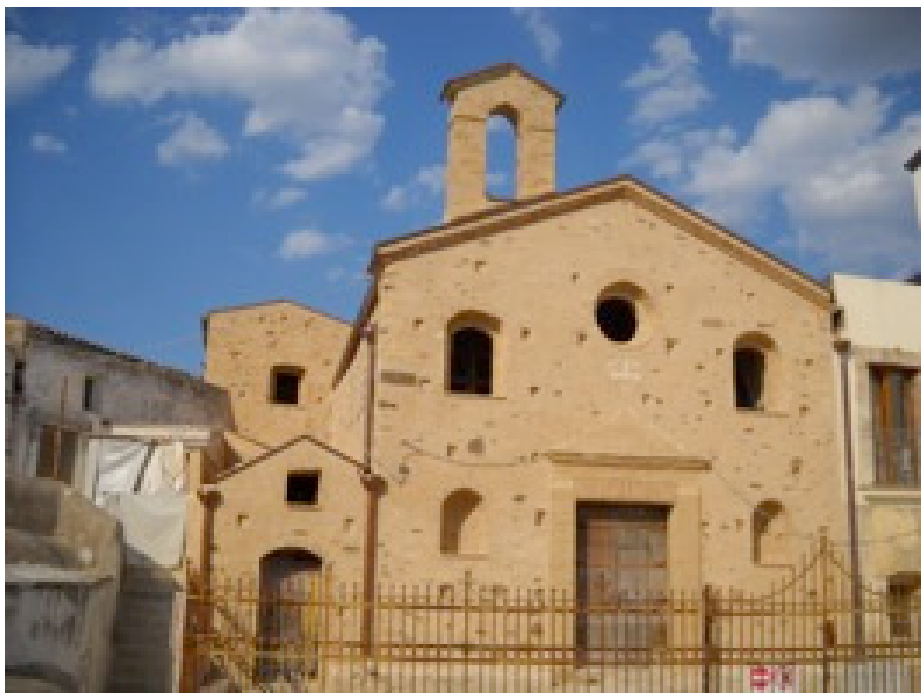

Figure 4: The church of San Rocco. 
meteoric water, the vaults and the walls have undergone a process of pathological aging rather accelerated. To the above said reasons it is added the age of the material and technological elements, the very irregular form of the masonry, the topsoil on the buttress of the vault (that saturated with the meteoric water increasing its volume and weight); it is clear that the structure of the cover was set to undergo a collapse by crushing, generating a damage state extremely evident. The same situation characterizes the load-bearing masonry with evident crack produced by crushing.

\section{In-situ test results}

In this section the experimental results of the double flat-jack tests obtained for the three investigated churches are reported. The results are shown and compared among them in the form of axial strain (horizontal and vertical) versus vertical stress acting into the tested masonry. In the case of Pio Monte dei Morti and San Rocco churches an injection grouting was applied to the masonry load-bearing elements. The masonry tests results of these churches are reported for the both conditions of before and after the mortar injection (conditions ante-operam and post-operam already mentioned), and are obtained on the same solid-unit masonry.

\subsection{The church of Madonna del Carmine}

The results of the double flat-jack test obtained for the masonry of the Madonna del Carmine church is depicted in Figure 5. The test was carried out placing one horizontal and four vertical displacement transducers with a measurement length of $400 \mathrm{~mm}$. To date is not yet available the result of the double flat-jack test reperformed on the same masonry specimen after the grout injection.

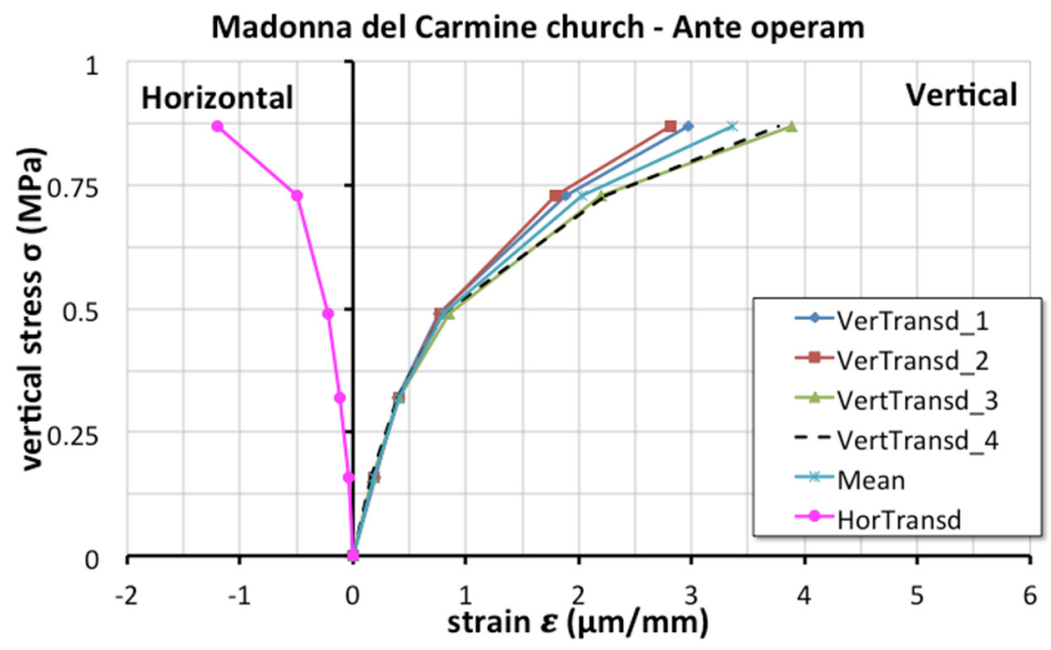

Figure 5: Madonna del Carmine double flat-jack test. Vertical stress in the masonry versus vertical and horizontal strain. 


\subsection{The churches of Pio Monte dei Morti and San Rocco}

In the case of Pio Monte dei Morti and San Rocco churches the double flat-jack test was repeated two times on the same masonry specimen. At first the masonry specimen investigated (Figure 6) was tested as built (ante-operam condition). Afterwards, in both the churches a diffused intervention of consolidation with grout injections was performed for repairing and strengthening the masonry of the walls. It was used a lime grout injected with a low pressure $(2.5 \mathrm{~atm})$ with a density of $50 \mathrm{~kg}$ per square meter.
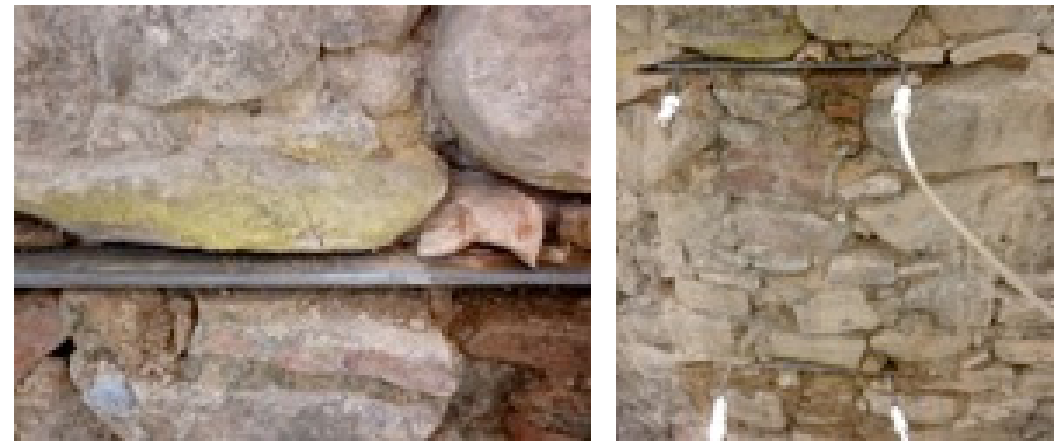

Figure 6: Double flat-jack test and masonry characterization.

The tests were performed placing one horizontal and three vertical displacement transducers with a measurement length of $300 \mathrm{~mm}$. In Figure 7 and Figure 8 the derived relationships between the vertical stress in the masonry and the horizontal (on the left) and vertical (on the right) strain are plotted. In each figure the mean stress-strain curve (dashed line) obtained from the curves related to each vertical displacement transducer is also reported.

\section{Comparisons and conclusions}

In Figure 9 are compared separately for ante and post operam conditions the stressstrain curves obtained for the three churches investigated.

The comparisons highlight that the grout injections produce a significant improvement of strength and stiffness of the masonry investigated. In fact, in the cases analysed grout injection permits of increasing the peak strength more than $200 \%$ (in the case of San Rocco church). It's worth noting that this intervention does not modify the elements aspects and increases the masonry durability since fills its cracks, voids and cavities within the material matrix. Moreover, the injections tend to uniform the quality and the mechanical properties of masonry all over the bearing elements on which is applied.

In the cases analysed the double flat jack test provides, for masonry with stone of irregular size and poor mortar, a compressive strength ranged between 0.58 $\mathrm{MPa}$ and $0.87 \mathrm{MPa}$. For the same masonry typology, for example, the Italian code [12] indicates instead a range of compressive strength of 1.00-1.80 MPa. 

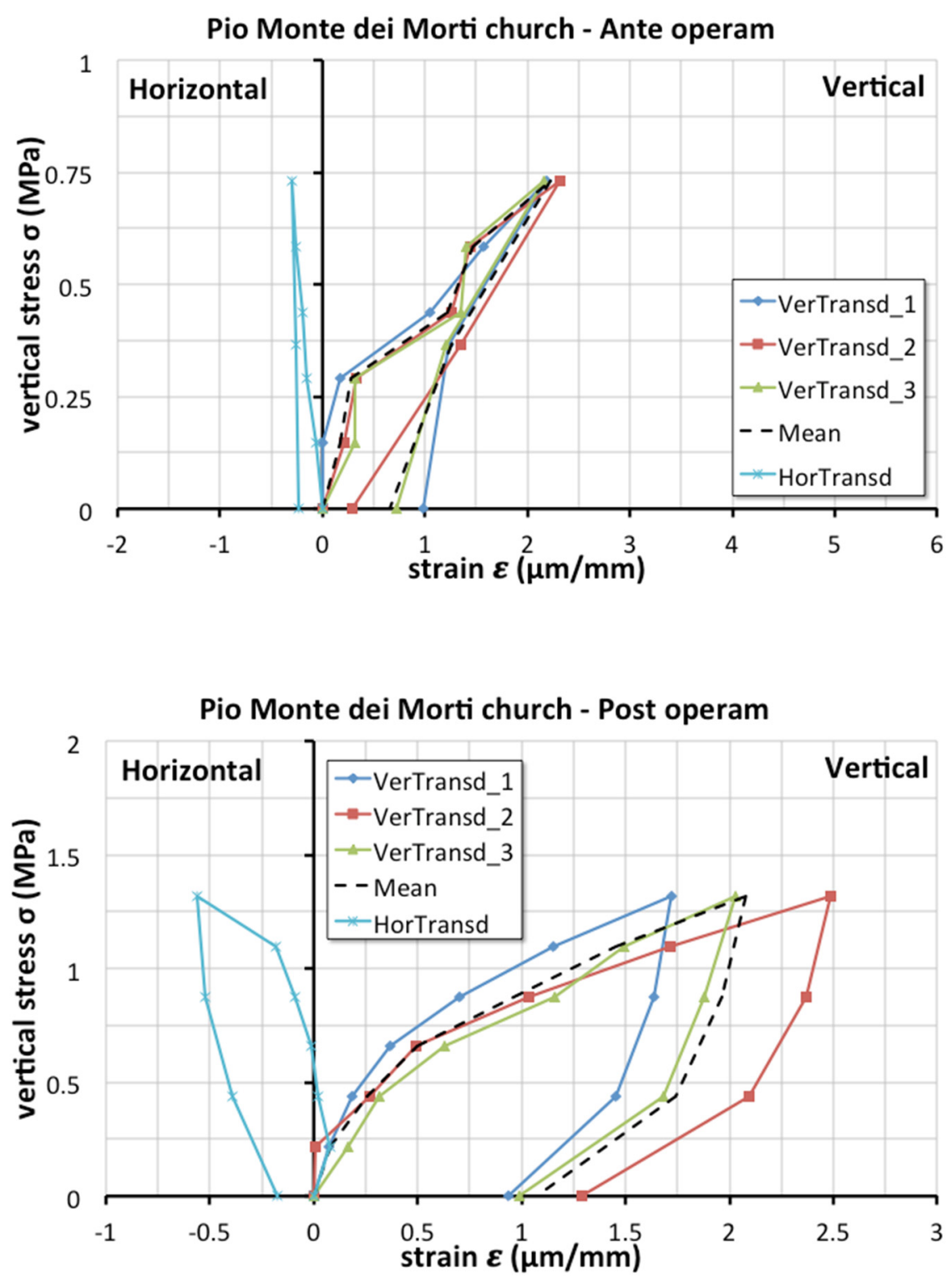

Figure 7: Pio dei Morti double flat-jack test. Vertical stress in the masonry versus vertical and horizontal strain ante-operam and with grout injection. 

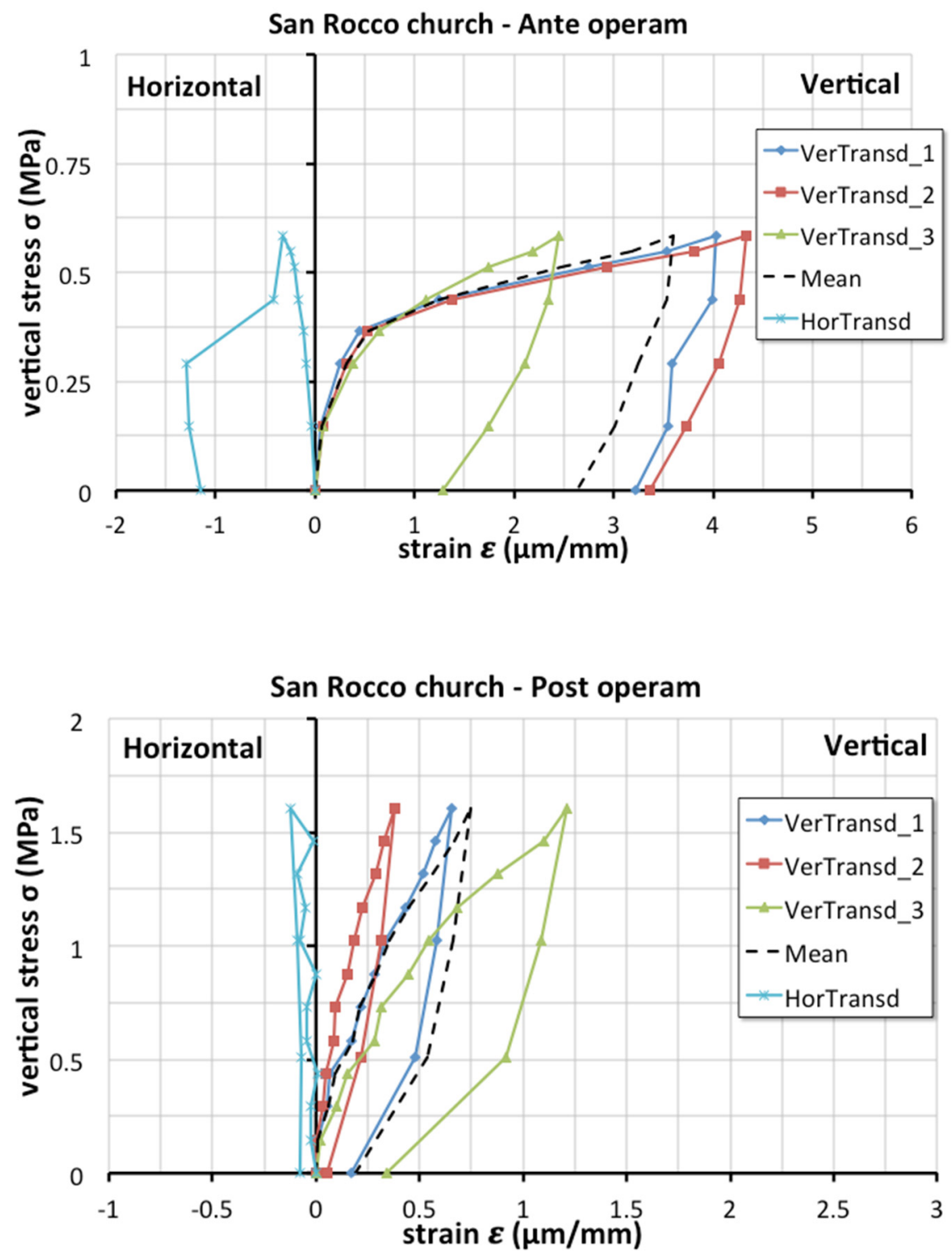

Figure 8: San Rocco double flat-jack test. Vertical stress in the masonry versus vertical and horizontal strain ante-operam and with grout injection. 

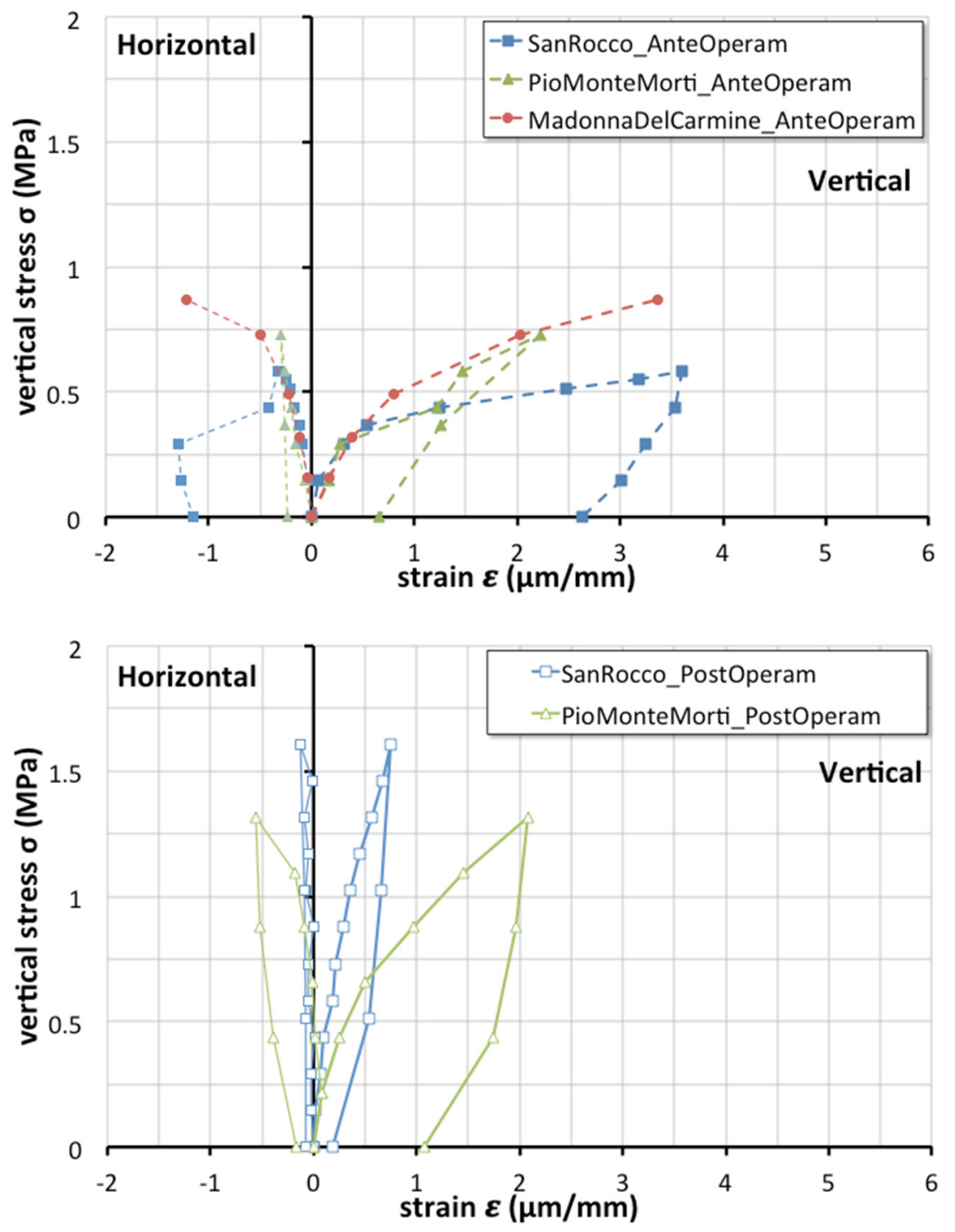

Figure 9: Comparisons among the stress-strain curves derived from the double flat-jack tests performed.

\section{References}

[1] Sollazzo A., Marzano S., Scienza delle costruzioni II - elementi di meccanica dei continui e resistenza dei materiali, UTET, Torino, 1998.

[2] Cigni G., Il consolidamento murario - tecniche d'intervento, Edizioni Kappa, Roma, 1999. 
[3] Pucinotti R., De Lorenzo R. A., Non-destructive in Situ Testing for the Seismic Damageability Assessment of "Ancient" R/C Structures, Proceedings of III International Conference on NDT, Crete, Greece, 2003.

[4] Pagliuca A., Guida A., Dimitrijevic B. "Reinforced Concrete Condition Assessment in Architectural Heritage. The Lion Chambers (Glasgow, UK) and the Theatre E. Duni (Matera, Italy)", prefazione di Amerigo Restucci, edito da CUES - Cooperativa Universitaria Editrice Studi, Fisciano, 2011.

[5] ASTM. Standard test method for in situ compressive stress within solid unit masonry estimated using flat-jack measurements. ASTM C1196-04, 2004.

[6] ASTM, In-situ measurement of masonry deformability properties using flatjack method, ASTM Standard C 1197-04, 2004.

[7] RILEM, Recommendation MDT.D.4: In-situ stress tests based on the flat jack, 2004.

[8] RILEM, Recommendation MDT.D.5: In-situ stress-strain behavior tests based on the flat jack, 2004.

[9] Pasquale D., "Cenni cronostorici di Pomarico", Matera, 1950.

[10] Tansi S., "Historia cronologica Monasterii S. Michaelis Archangeli Montis Caveosi Congregationis Casinensis Ordinis Sancti Benedicti ab anno MLXV ab annum MCDLXXXIV, Neapoli MDCCXLVI", Matera.

[11] Carbonara G., "Trattato di restauro architettonico", UTET, vol. II, Torino, 1987.

[12] Italian Code, D.M. 14/01/2008. Norme Tecniche per le costruzioni, 2008. 